\title{
Influence of continuous erythropoietin receptor activator (CERA) administration intervals on erythropoietic effect in hemodialysis patients
}

\author{
Shoichiro Daimon ${ }^{1 *}$, Hiromi Nuka ${ }^{2}$, Kinya Kitada ${ }^{2}$, Yasunori Suzuki ${ }^{2}$, Fae Kim ${ }^{2}$ and Mitsuhiro Kawano ${ }^{2}$
}

\begin{abstract}
Background: Erythropoietin deficiency is the major cause of anemia in hemodialysis patients. Although continuous erythropoietin receptor activator (CERA) has a long half-life and once-monthly administration is recommended, the optimal interval to achieve the greatest efficacy is not known.

Methods: In 44 hemodialysis patients, CERA was administered at an interval of once every 2 weeks (Q2W) and 4 weeks (Q4W) consecutively and reticulocyte counts and hemoglobin levels were compared prospectively. In six patients with CERA $100 \mu \mathrm{g} / 4$ weeks, CERA intervals were further changed to 1 week (Q1W).

Results: Mean reticulocyte counts were higher during Q2W than Q4W (41.5 \pm 10.7 and $36.4 \pm 8.8 \times 10^{3} / \mu \mathrm{L}$, respectively, $p<0.0001)$, and hemoglobin levels decreased during Q4W. These results were irrespective of the CERA dose $(50,100$, and $150 \mu \mathrm{g} / 4$ weeks). In six patients with CERA $100 \mu \mathrm{g} / 4$ weeks, although not significant, reticulocyte counts were higher during Q2W and Q1W than Q4W and hemoglobin levels were highest during Q1W $(p<0.05)$.

Conclusions: In our hemodialysis patients, an interval of CERA shorter than 4 weeks appeared to be more effective for the treatment of anemia.
\end{abstract}

Keywords: CERA, Interval, Reticulocyte, Hemoglobin

\section{Background}

Anemia is common in patients with chronic renal failure. Its causes include erythropoietin (EPO) deficiency, iron deficiency, inflammation, hyperparathyroidism, and in hemodialysis patients, blood loss related to the hemodialysis procedure. Although all these factors contribute to the anemia of hemodialysis patients, EPO deficiency is thought to be the major one. Anemia is associated with poorer patient survival $[1,2]$ and quality of life [3]. After the introduction of erythropoietinstimulating agents (ESAs), the management of renal anemia has improved and has been associated with improved survival of hemodialysis patients [4].

\footnotetext{
* Correspondence: dai-clinic@m2.spacelan.ne.jp

${ }^{1}$ Department of Nephrology, Daimon Clinic for Internal Medicine,

Nephrology and Dialysis, Oshino 1-400, Nonoichi, Ishikawa-pref 921-8802,

Japan

Full list of author information is available at the end of the article
}

Traditional ESAs have relatively short intravenous half-lives (epoetin alfa and beta, 7-9 h) [5] and require frequent administration. Continuous erythropoietin receptor activator (CERA) has a long half-life (134 and $139 \mathrm{~h}$ following intravenous and subcutaneous administration, respectively) [6] and is administered at wider intervals than epoetin or darbepoetin alfa for renal anemia in patients with chronic kidney disease. Although conversion to CERA with intervals of once every 2 weeks $(\mathrm{Q} 2 \mathrm{~W})$ or 4 weeks (Q4W) from other ESAs is achieved safely in hemodialysis patients and oncemonthly administration is recommended in Japan, the optimal interval of CERA administration is not known. Recently, it is reported that more continuous erythropoiesis was achieved with a Q2W administration of CERA than Q4W [7], and Q2W administration of CERA is more effective than Q4W to achieve target hemoglobin $(\mathrm{Hb})$ levels [8]. Although we also reported more effective 
erythropoiesis of CERA by Q2W than Q4W, the fluctuation of $\mathrm{Hb}$ levels during Q4W is greater than that during Q2W [9], which makes it difficult to compare the true effect of the interval of CERA administration on $\mathrm{Hb}$ levels.

Usually the responsiveness to ESAs in hemodialysis patients is defined by the ESA dose and Hb levels [10], with low $\mathrm{Hb}$ levels at the same dose of ESAs meaning hypo-responsiveness to ESAs. This "responsiveness" is not equal to "red blood cell (RBC) production". In the absence of considerable blood loss, Hb levels are affected not only by the $\mathrm{RBC}$ production rate but also by the death rate, which means RBC lifespan. In hemodialysis patients, shortened and high interindividual variability of RBC lifespan is reported [11] and may have a substantial impact on $\mathrm{Hb}$ levels, which has been largely neglected.

For these reasons, $\mathrm{Hb}$ levels alone are not suitable to evaluate the erythropoietic effect of CERA according to administration interval, which prompted us to compare also reticulocyte counts during 4-, 2-, and 1-week intervals of CERA administration.

\section{Methods}

This prospective study focused on 44 hemodialysis patients in Daimon Clinic for Internal Medicine, Nephrology and Dialysis, whose $\mathrm{Hb}$ levels were controlled between 9 and $12 \mathrm{~g} / \mathrm{dL}$ without changes in the CERA dose administered by Q2W for more than 3 months. Table 1 shows patient characteristics at baseline. $\mathrm{Hb}$ was controlled within a narrow range $(10.9 \pm 0.8 \mathrm{~g} / \mathrm{dL})$ under the same dosage of CERA administered by Q2W $(50 \mu \mathrm{g}$ per 4 weeks, $N=25 ; 100 \mu \mathrm{g}, N=13$; and $150 \mu \mathrm{g}, N=6$ ). Serum levels of hepcidin-25 were measured using a liquid chromatography-tandem mass spectrometric method [12]. Reticulocyte counts and Hb levels were evaluated every week for 4 weeks, and then CERA administration intervals were changed to 4 weeks (same dosage per 4 weeks). After the 4-week wash-out period, weekly reticulocyte counts and $\mathrm{Hb}$ levels were evaluated again for 4 weeks. To compare the erythropoietic effect of CERA by Q2W and Q4W, we evaluated the mean reticulocyte counts of the first hemodialysis session of the week during the 4 weeks of the evaluation period.

In 6 of 13 patients, $100 \mu \mathrm{g}$ of CERA was administered every 4 weeks and $\mathrm{Hb}$ levels were between 9 and $12 \mathrm{~g} / \mathrm{dL}$ at the end of the above study, after which CERA intervals were further changed to 1 week (Q1W) $(25 \mu \mathrm{g}$ of CERA every week) and reticulocyte counts and $\mathrm{Hb}$ levels were evaluated prospectively for a further 8 weeks (Fig. 1).

As a rule, iron has been administered orally in our clinic, with intravenous iron not administered during the study period. In 28 of the 44 patients, oral iron had been prescribed every day at least 3 months before the study (sodium ferrous citrate, $N=21$; ferric citrate, $N=7$, respectively) and did not change during the study period.

This study was approved by the local ethics committee (issue 2014-A1 at Daimon Clinic for Internal Medicine, Nephrology and Dialysis), and written informed consent was obtained from all patients.

\section{Statistical analyses}

Data were expressed as the mean \pm SD. Paired and unpaired $t$ tests and chi square test were used to compare the data. Statistical significance is defined as $p$ less than 0.05 .

\section{Results}

Figure 2 shows the weekly changes of reticulocyte counts during CERA administration by Q2W and Q4W. Three groups by CERA dose (50, 100, and $150 \mu \mathrm{g} / 4 \mathrm{~W})$ showed a similar pattern of reticulocyte count changes. As shown in Table 2, mean reticulocyte counts were higher during Q2W than during Q4W irrespective of CERA dose $(p<0.005, p<0.05$, and $p<0.05$ for CERA 50, 100, and $150 \mu \mathrm{g} / 4 \mathrm{~W}$, respectively). Although $\mathrm{Hb}$ levels were stable during the period of CERA by Q2W, after the switch to Q4W, Hb levels showed a tendency to decrease (Fig. 3).

In six patients with CERA $100 \mu \mathrm{g}$ per 4 weeks who were switched to Q1W further, as shown in Fig. 4, reticulocyte counts were maximal $\left(50-56 \times 10^{3} / \mu \mathrm{L}\right)$ around 2 weeks after the switch to Q1W and $\mathrm{Hb}$ increased gradually and reached a plateau 6 weeks after the switch to Q1W. Mean reticulocyte counts during the evaluation periods of Q4W, Q2W, and Q1W were 34.6 $\pm 22.3,41.9 \pm 19.9$, and $38.3 \pm 10.8 \times 10^{3} / \mu \mathrm{L}$, respectively $(p=$ n.s.). Mean Hb levels were 11.1 $\pm 0.9,11.2 \pm 1.3$, and $12.0 \pm 2.2 \mathrm{~g} / \mathrm{dL}$, respectively $(p<0.05 \mathrm{Q} 1 \mathrm{~W}$ vs. Q2W and Q1W vs. Q4W). Serum iron and ferritin levels at the switch to Q1W were $105.3 \pm 42.5 \mu \mathrm{g} / \mathrm{dL}$ and $145.3 \pm$ $81.5 \mathrm{ng} / \mathrm{mL}$, and 8 weeks later, $75.3 \pm 40.9 \mu \mathrm{g} / \mathrm{dL}(p=\mathrm{n} . \mathrm{s}$. $)$ and $91.6 \pm 109.6 \mathrm{ng} / \mathrm{mL}(p<0.05)$, respectively.

\section{Discussion}

EPO deficiency is the major cause of anemia in patients with chronic renal failure. ESAs correct anemia by binding to erythropoietin receptors expressed on progenitor cells in the bone marrow which leads to inhibition of cell apoptosis and enhancement of proliferation and differentiation [13]. The stimulated progenitor cells differentiate to erythroblasts, then mature to reticulocytes and finally to RBCs. Hematopoiesis by ESA administration influences iron metabolism. Although the precise mechanisms are not clear, in hemodialysis patients, ESA administration exerts a biphasic pattern of serum hepcidin-25 levels; early upregulation followed by late downregulation [14], and low serum hepcidin levels 
Table 1 Patient characteristics at baseline

\begin{tabular}{|c|c|c|c|c|c|c|c|c|c|c|c|c|c|}
\hline $\begin{array}{l}\text { CERA dosage } \\
(\mu \mathrm{g} / 4 \text { weeks) }\end{array}$ & Male (\%) & Age (years) & Diabetes (\%) & $\begin{array}{l}\text { HD vintage } \\
\text { (months) }\end{array}$ & $\begin{array}{l}\text { BUN } \\
(\mathrm{mg} / \mathrm{dL})\end{array}$ & $\begin{array}{l}\mathrm{Cr} \\
(\mathrm{mg} / \mathrm{dL})\end{array}$ & $\begin{array}{l}\text { TP } \\
(\mathrm{g} / \mathrm{dL})\end{array}$ & $\begin{array}{l}\text { Alb } \\
\text { (g/dL) }\end{array}$ & $\begin{array}{l}\mathrm{Hb} \\
(\mathrm{g} / \mathrm{dL})\end{array}$ & $\begin{array}{l}\text { CRP } \\
(\mathrm{mg} / \mathrm{dL})\end{array}$ & $\mathrm{Fe}(\mu \mathrm{g} / \mathrm{dL})$ & Ferritin (ng/mL) & $\begin{array}{l}\text { Hepcidin-25 } \\
\text { (ng/mL) }\end{array}$ \\
\hline $50(N=25)$ & $16(64.0)$ & $\begin{array}{l}70.0 \pm 11.3 \\
(35-87)\end{array}$ & $13(52.0)$ & $105.5 \pm 90.6$ & $62.6 \pm 13.6$ & $10.7 \pm 2.1$ & $6.5 \pm 0.5$ & $3.8 \pm 0.3$ & $10.9 \pm 0.8$ & $0.35 \pm 0.53$ & $\begin{array}{l}79.7 \pm 26.0 \\
(36-123)\end{array}$ & $\begin{array}{l}143.2 \pm 155.0 \\
(16.1-824)\end{array}$ & $\begin{array}{l}74.2 \pm 41.9 \\
(0.4-175.9)\end{array}$ \\
\hline $100(N=13)$ & $9(69.2)$ & $\begin{array}{l}70.6 \pm 7.7 \\
(53-85)\end{array}$ & $4(30.8)$ & $67.4 \pm 66.4$ & $67.5 \pm 14.2$ & $10.4 \pm 1.9$ & $6.7 \pm 0.3$ & $3.7 \pm 0.3$ & $11.0 \pm 0.7$ & $0.25 \pm 0.52$ & $\begin{array}{l}82.1 \pm 31.7 \\
(32-145)\end{array}$ & $\begin{array}{l}89.1 \pm 70.4 \\
(25.1-233)\end{array}$ & $\begin{array}{l}38.9 \pm 33.6 \\
(0.2-122)\end{array}$ \\
\hline $150(N=6)$ & $5(83.3)$ & $\begin{array}{l}69.0 \pm 9.3 \\
(51-75)\end{array}$ & $5(83.3)$ & $88.5 \pm 45.4$ & $57.9 \pm 23.2$ & $9.1 \pm 4.0$ & $6.6 \pm 0.4$ & $3.3 \pm 0.2$ & $10.4 \pm 1.0$ & $2.46 \pm 3.17$ & $\begin{array}{l}44.8 \pm 15.8 \\
(26-68)\end{array}$ & $\begin{array}{l}128.6 \pm 89.6 \\
(54.6-263)\end{array}$ & $\begin{array}{l}90.2 \pm 29.3 \\
(55.7-137.1)\end{array}$ \\
\hline All $(N=44)$ & $30(68.2)$ & $\begin{array}{l}70.0 \pm 9.9 \\
(35-87)\end{array}$ & $22(50.0)$ & $91.9 \pm 79.6$ & $63.4 \pm 15.2$ & $10.4 \pm 2.4$ & $6.6 \pm 0.4$ & $3.7 \pm 0.3$ & $10.9 \pm 0.8$ & $0.61 \pm 1.40$ & $\begin{array}{l}75.6 \pm 29.0 \\
(26-145)\end{array}$ & $\begin{array}{l}125.2 \pm 127.7 \\
(16.1-824)\end{array}$ & $\begin{array}{l}66.0 \pm 41.7 \\
(0.2-175.9)\end{array}$ \\
\hline
\end{tabular}

Variables are represented as mean \pm standard deviation

$H D$ hemodialysis, BUN blood urea nitrogen, $\mathrm{Cr}$ creatinine, $T P$ total protein, Alb albumin, $H b$ hemoglobin, CRP C-reactive protein, $F e$ iron 




Fig. 1 Study design schema

facilitate iron utilization, which results in a decrease of serum ferritin levels. The degree of iron utilization and recruitment to the hematopoietic system seems to differ according to the type of ESAs [14-16] and interval of dosing $[7,8]$. Transient reduction of serum hepcidin and ferritin levels induced by CERA administration reach a maximum around 1 week after dosing and return to pre-administration levels by 4 weeks, with this being the rationale of the once-monthly administration of CERA. These transient changes of serum ferritin and hepcidin levels induced by CERA are considered to be due to sustained stimulation of erythropoiesis by CERA which lasts

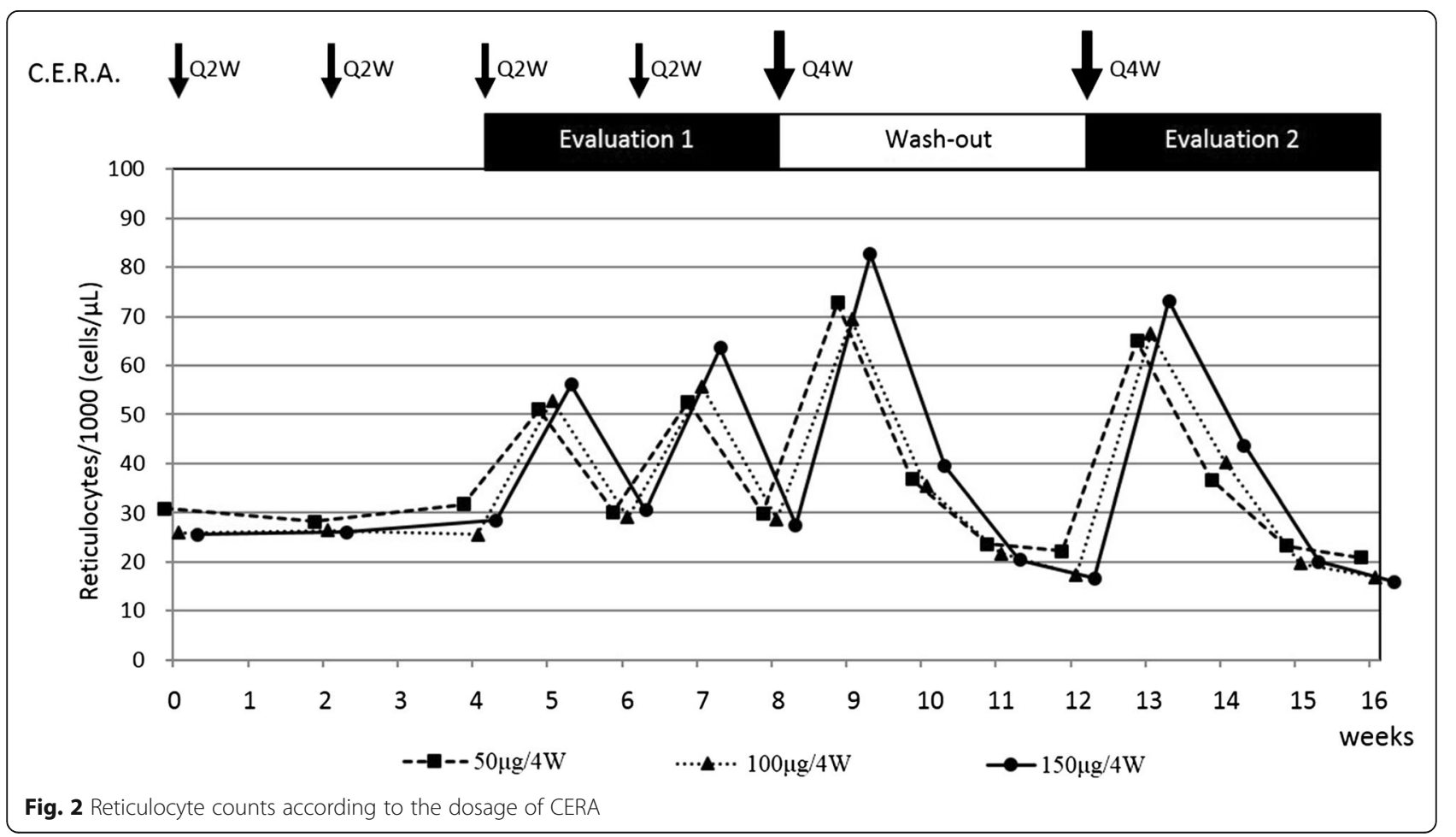


Table 2 Mean reticulocyte counts during the administration of CERA by Q2W and Q4W

\begin{tabular}{llll}
\hline $\begin{array}{l}\text { CERA dosage } \\
(\mu \mathrm{g} / 4 \text { weeks })\end{array}$ & $\begin{array}{l}\mathrm{Q} 2 \mathrm{~W} / 1000 \\
(\mathrm{cell} / \mu \mathrm{L})\end{array}$ & $\begin{array}{l}\mathrm{Q} 4 \mathrm{~W} / 1000 \\
(\mathrm{cell} / \mu \mathrm{L})\end{array}$ & $p$ value \\
\hline $50(N=25)$ & $40.7 \pm 10.0$ & $36.2 \pm 9.9$ & $<0.005$ \\
$100(N=13)$ & $41.6 \pm 12.5$ & $35.8 \pm 7.8$ & $<0.05$ \\
$150(N=6)$ & $44.7 \pm 10.8$ & $38.4 \pm 7.0$ & $<0.05$ \\
All $(N=44)$ & $41.5 \pm 10.7$ & $36.4 \pm 8.8$ & $<0.0001$ \\
\hline
\end{tabular}

Variables are represented as mean \pm standard deviation

much longer than that induced by epoetin. Although CERA has a long half-life, and once-monthly administration of CERA is safe and reported to save up to 144 injections per hemodialysis patient per year compared with three times weekly dosing [17], it is reported that Q2W administration of CERA is more effective than Q4W to achieve target $\mathrm{Hb}$ levels [7, 8, 17], which made us wonder what would be the optimal interval of CERA administration from the standpoint of efficacy.

As shown in Table 2, our study demonstrated higher mean reticulocyte counts in patients with CERA administered at Q2W than Q4W. In six patients, we further evaluated $\mathrm{Hb}$ levels and reticulocyte counts after CERA was administered by Q2W, Q4W, and Q1W sequentially (Fig. 4). During Q1W, $\mathrm{Hb}$ increased gradually and reached a higher level than that during Q2W and Q4W. Reticulocyte counts were highest in the first 2-4 weeks during the period of $\mathrm{Q} 1 \mathrm{~W}$ and persisted around the same levels as those of Q2W. Although timing effect of CERA administration on serum iron and ferritin levels must be taken into consideration, decrease of serum iron and ferritin levels during Q1W may indicate more effective iron recruitment for erythropoiesis than Q4W. Although the number of patients on Q1W was very small, this result suggests that not only Q2W but also Q1W administration of CERA has a greater erythropoietic effect than Q4W, and Q1W may have more potential to increase Hb levels than Q2W.

For the production of RBCs, erythropoietin is mandatory, since otherwise erythroid progenitor cells are rapidly lost to apoptosis [18]. Although CERA has a longer half-life than traditional ESAs, our results suggest that 4 weeks as a CERA administration interval is too long to achieve sustained erythropoiesis, and it is anticipated that the longer the interval of CERA administration is, the more erythroid progenitor cells might be lost to apoptosis, resulting in a decrease in the $\mathrm{RBC}$ production rate.

We evaluated the erythropoietic effect of CERA administered at different intervals by comparing reticulocyte counts and $\mathrm{Hb}$ levels. For this purpose, the CERA dose had to be kept stable during the study period. But it is sometimes difficult to maintain $\mathrm{Hb}$ levels within the target ranges without changing the dose of CERA for a substantial period, which meant that the study period had to be rather short. Especially when the CERA interval changes, $\mathrm{Hb}$ levels become unstable, and so as the wash-out period of

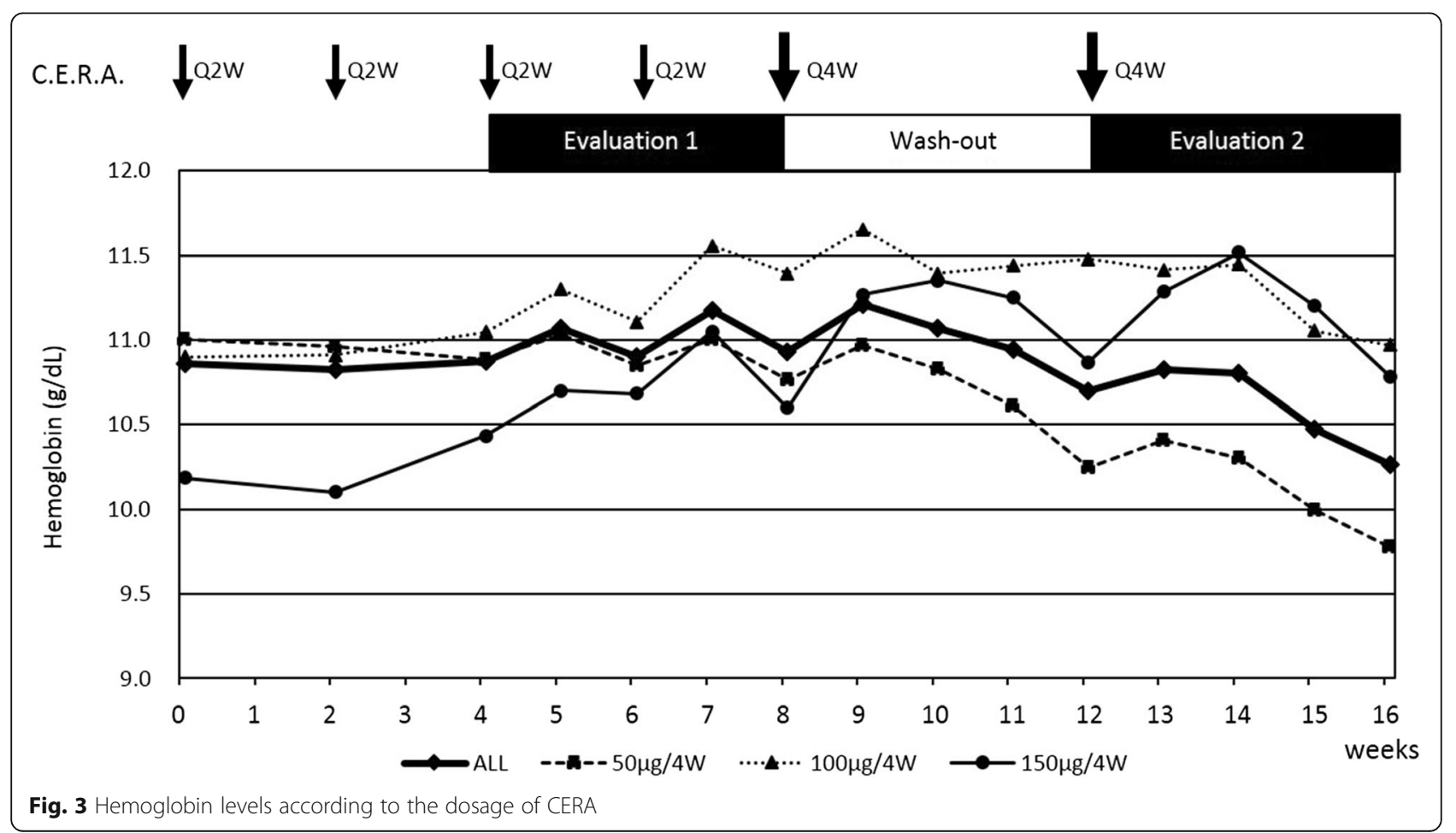




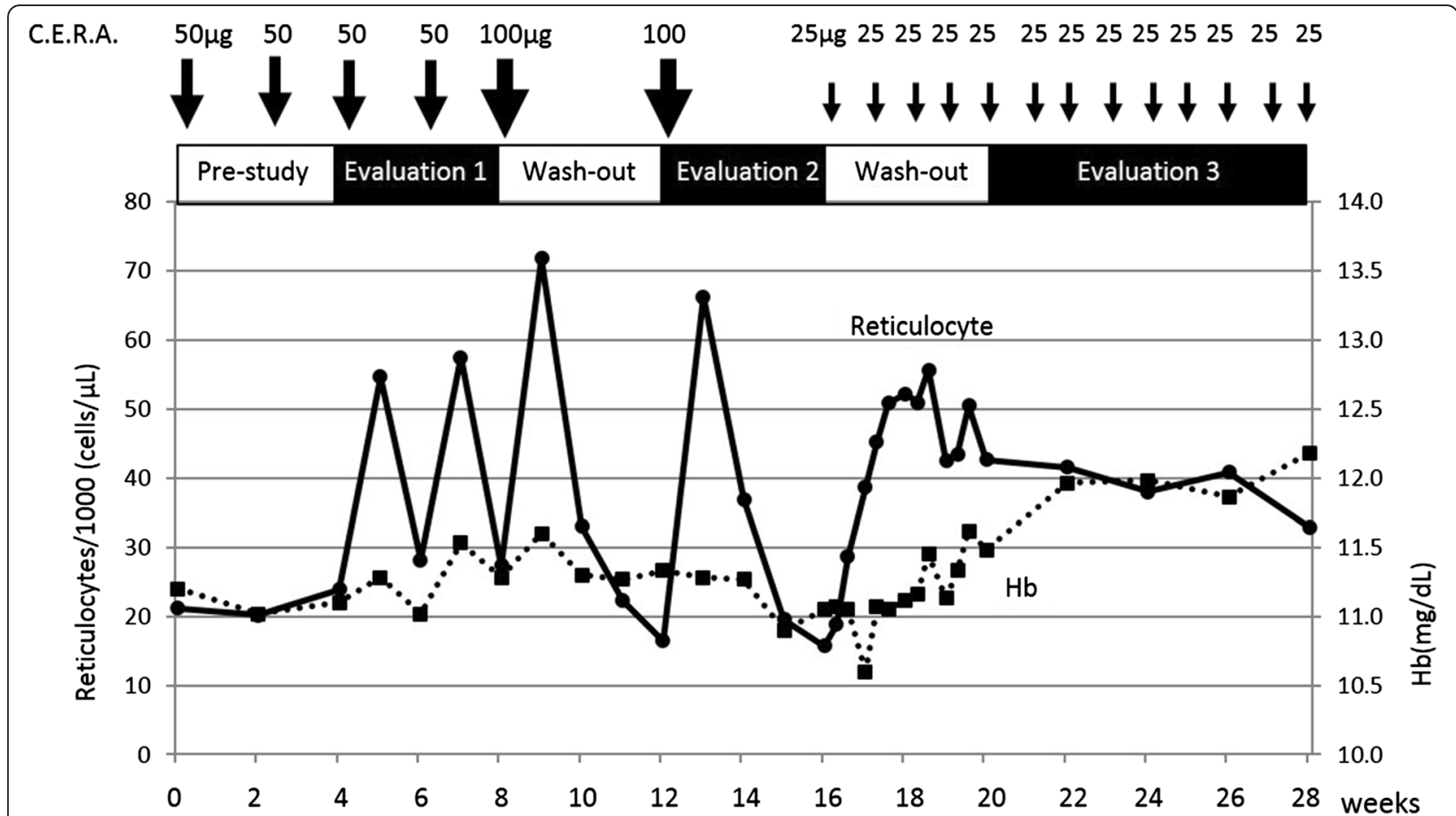

Fig. 4 Reticulocyte counts and hemoglobin levels when $100 \mu \mathrm{g}$ of CERA per 4 weeks was administered by Q2W, Q4W, and Q1W

evaluation of CERA administration, we adopted only 4 weeks provisionally. As shown in Fig. 5, which illustrates the changes of reticulocyte counts and $\mathrm{Hb}$ levels during $100 \mu \mathrm{g}$ of CERA, as Q4W was missed (this patient was excluded from evaluation in this study), reticulocyte counts decreased to minimal values at 4 weeks after the administration of CERA and persisted at the same level until the next administration of CERA. Although this is just a single observational datum, this example suggests that the

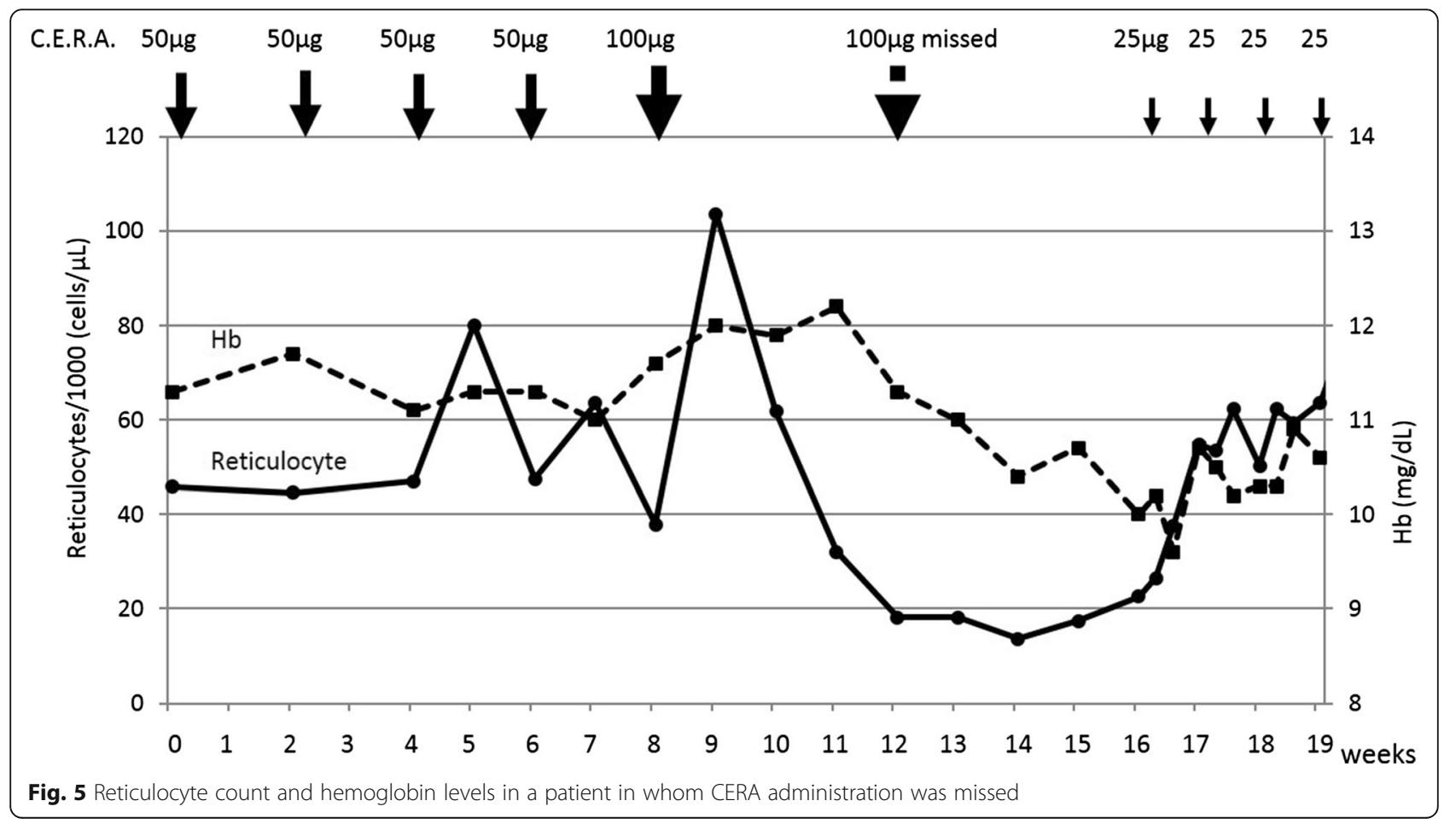


erythropoietic effect of CERA is not sustained for more than 4 weeks. This is in accordance with the reports of reticulocyte dynamics in hemodialysis patients treated with CERA $[15,19]$.

To compare the $\mathrm{Hb}$ levels of hemodialysis patients with CERA administered by different intervals, as we reported elsewhere [9], we need to consider the fluctuation patterns of $\mathrm{Hb}$ levels, which differ according to the CERA interval. Reticulocyte counts were maximal at 710 days of CERA administration and returned to the same levels by the next monthly CERA administration $[15,19]$, which influenced $\mathrm{Hb}$ levels. As a result, not only reticulocyte counts but also $\mathrm{Hb}$ levels differ according to the timing of the CERA administration and bloodwork, with the timing effect more prominent when CERA administration intervals are longer. This is also the case when we evaluate the serum iron, ferritin, or hepcidin levels which change in a mirror-image manner to the reticulocyte counts $[7,9,15,19]$.

In this study, $\mathrm{Hb}$ levels in the three groups of patients with CERA at doses of 50,100, and $150 \mu \mathrm{g}$ per 4 weeks were the same, which means that as a whole patients in the group with smaller dose of CERA have a higher responsiveness to CERA than patients in the group with a larger dose. But this "responsiveness" to ESAs is not equivalent to the "RBC production rate" by ESAs. The anemia of hemodialysis patients is not exclusively attributable to hypoproduction of RBCs. In the absence of considerable blood loss due to hemorrhage or the hemodialysis procedure itself, $\mathrm{Hb}$ levels of hemodialysis patients are affected by a shortened RBC lifespan. In healthy adults, the RBC lifespan is about 120 days within a narrow distribution. On the other hand, it is reported that in hemodialysis patients, the mean RBC lifespan is 89 days with high interindividual variability [11]. Although the influence of RBC lifespan on $\mathrm{Hb}$ levels in hemodialysis patients is substantial, this factor has been largely neglected [20]. In hemodialysis patients, RBC lifespan is influenced by the uremic state [21, 22], ESA administration [19, 23], and/or inflammation. The higher levels of CRP and hepcidin and lower levels of iron in patients receiving CERA $150 \mu \mathrm{g} / 4 \mathrm{~W}$ than in those receiving 100 or $50 \mu \mathrm{g} / 4 \mathrm{~W}$ may indicate the bluntness of iron recruitment for erythropoiesis but may also indicate a shorter RBC lifespan in patients requiring higher doses of CERA. Also, the highest level of $\mathrm{Hb}$ seen during evaluation 3 as compared to that during evaluation 1 and 2 with the same reticulocyte counts may suggest a longer RBC lifespan during Q1W of CERA than that during Q2W and Q4W.

For the effective treatment of anemia in hemodialysis patients, we need to consider multiple factors such as iron deficiency, inflammation, hyperparathyroidism, and dialysis dose and adjust them whenever possible. Also our study suggests that by changing the interval of CERA, the CERA dose can be reduced without exacerbating $\mathrm{Hb}$ control. Moreover, it is anticipated that the more sustained erythropoiesis and $\mathrm{RBC}$ production associated with a shorter interval of CERA can prevent the occurrence of $\mathrm{Hb}$ overshoot or $\mathrm{Hb}$ cycling. Although any effects of such factors on the mortality of hemodialysis patients have not been well documented [24], a shorter interval of CERA administration has advantages in stabilizing $\mathrm{Hb}$ levels, reducing the cost of ESAs, and reducing the workload associated with frequent changes of the ESA dose.

\section{Conclusions}

In hemodialysis patients, a shorter interval of CERA administration can produce more $\mathrm{RBC}$ and increase $\mathrm{Hb}$ levels. To achieve efficient and sustained RBC production and maintenance of $\mathrm{Hb}$ levels within the narrow target range, shorter than a 4-week interval of CERA administration appears preferable.

\section{Abbreviations \\ CERA: Continuous erythropoietin receptor activator; EPO: Erythropoietin; ESA: Erythropoietin-stimulating agent; Q2W: Once every 2 weeks; $\mathrm{Hb}$ : Hemoglobin; RBC: Red blood cell}

\section{Acknowledgements \\ The authors thank all staff members working at Daimon Clinic for Internal Medicine, Nephrology and Dialysis. \\ Funding \\ This study was not supported by any grants or funding. \\ Availability of data and materials \\ The datasets during and/or analyzed during the current study are available from the corresponding author on reasonable request.}

\section{Authors' contributions}

$\mathrm{HN}, \mathrm{KK}, \mathrm{YS}$, and FK participated in the design of the study. MK conceived of the study and participated in its design. SD was responsible for the research idea and study. All authors read and approved the final manuscript.

\section{Competing interests}

The authors declare that they have no competing interests.

\section{Consent for publication}

Not applicable

\section{Ethics approval and consent to participate}

This study was approved by the local ethics committee (issue 2014-A1 at Daimon Clinic for Internal Medicine, Nephrology and Dialysis), and written informed consent was obtained from all patients.

\section{Author details}

'Department of Nephrology, Daimon Clinic for Internal Medicine, Nephrology and Dialysis, Oshino 1-400, Nonoichi, Ishikawa-pref 921-8802, Japan. ${ }^{2}$ Division of Rheumatology, Department of Internal Medicine, Kanazawa University Graduate School of Medicine, Kanazawa, Japan.

Received: 5 September 2015 Accepted: 19 October 2016

Published online: 02 November 2016

\section{References}

1. Ma JZ, Ebben J, Xia H, Xia H, Collins AJ. Hematocrit level and associated mortality in hemodialysis patients. J Am Soc Nephrol. 1999;10:610-9. 
2. Foley RN, Parfrey PS, Morgan J, et al. Effect of hemoglobin in hemodialysis patients with asymptomatic cardiomyopathy. Kidney Int. 2000;58:1325-35.

3. Perlman RL, Finkelstein FO, Liu L, et al. Quality of life in chronic kidney disease (CKD): a cross-sectional analysis in the Renal Research Institute-CKD study. Am J Kidney Dis. 2005;45:658-66.

4. Regidor DL, Kopple JD, Kovesdy CP, et al. Association between changes in hemoglobin and administered erythropoietin-stimulating agent and survival in hemodialysis patients. J Am Soc Nephrol. 2006;17:1181-91.

5. Halstenson CE, Macres M, Katz SA, et al. Comparative pharmacokinetics and pharmacodynamics of epoetin alfa and epoetin beta. Clin Pharmacol Ther. 1991;50:702-12.

6. Macdougal IC, Robson R, Opatrna S, et al. Pharmacokinetics and pharmacodynamics of intravenous and subcutaneous continuous erythropoietin receptor activator (CERA) in patients with chronic kidney disease. Clin J Am Soc Nephrol. 2006;1:1211-5.

7. Morikami Y, Fujimori A, Okada S, Kumei M, Mizobuchi N, Sakai M. Comparison of 2-week versus 4-week dosing intervals of epoetin beta pegol on erythropoiesis and iron metabolism in hemodialysis patients. Ther Apher Dial. 2014;18:414-20.

8. Toida T, Sato Y, Shibata N, Kitamura K, Fujimoto S. A randomized control study on the procedure for switching epoetin beta (EPO) to epoetin beta pegol (CERA) in the treatment of renal anemia in maintenance hemodialysis patients. Blood Purif. 2014;38:174-9.

9. Daimon S. Comparison of the effect of the same dose of a 4-weekly continuous erythropoietin receptor activator administered once every 2 or 4 weeks in hemodialysis patients. Ther Apher Dial. 2014;18:518-21.

10. Fukuma S, Yamaguchi T, Hashimoto $S$, et al. Erythropoiesis-stimulating agent responsiveness and mortality in hemodialysis patients: results from a cohort study from the dialysis registry in Japan. Am J Kidney Dis. 2012;59:108-16.

11. Sato Y, Mizuguchi T, Shigenaga S, et al. Shortened red blood cell lifespan is related to the dose of erythropoiesis-stimulating agents requirement in patients on hemodialysis. Ther Apher Dial. 2012;16:522-8.

12. Itkonen O, Parkkinen J, Stenman UH, Hämäläinen E. Preanalytical factors and reference intervals for serum hepcidin LC-MS/MS method. Clin Chim Acta. 2012;413:696-701.

13. Fisher JW. Erythropoietin: physiology and pharmacology update. Exp Biol Med. 2003;228:1-14.

14. Takasawa K, Tomosugi N, Takaeda C, Maeda T, Ueda N. Regulation of hepcidin-25 by short and long-acting rhEPO may be dependent on ferritin and predict the response to rhEPO in hemodialysis patients. Nephron Extra. 2014:4:55-63.

15. Jonckheere S, Dierick J, Vanhouteghem H, Devieeschouwer M, Stove V. Erythrocyte indices in the assessment of iron states in dialysis-dependent patients with end-stage renal disease on continuous erythropoietin receptor activator versus epoetin $\beta$ therapy. Acta Haematol. 2010;124:27-33.

16. Kakimoto-Shino M, Toya Y, Kuji T, Fujikawa T, Umemura S. Changes in hepcidin and reticulocyte levels in response to continuous erythropoietin receptor activator administration in hemodialysis patients: a randomized study. Ther Apher Dial. 2014:18:421-6.

17. Sulowicz W, Locatelli F, Ryckelynck JP, et al. Once-monthly subcutaneous C. E.R.A. maintains stable hemoglobin control in patients directly from epoetin one to three times weekly. Clin J Am Soc Nephrol. 2007;2:637-46.

18. Polenakovic M, Sikole A. Is erythropoietin a survival factor for red blood cells? J Am Soc Nephrol. 1996;7:1178-82.

19. Forni V, Bianchi G, Ogna A, et al. Reticulocyte dynamic and hemoglobin variability in hemodialysis patients treated with Darbepoetin alfa and C.E.R. A.: a randomized controlled trial. BMC Nephrol. 2013;14:157-66.

20. Kalicki RM, Uehlinger DE. Red cell survival in relation to changes in the hematocrit: more important than you think. Blood Purif. 2008;26:355-60.

21. Erslev AJ, Besarab A. The rate and control of baseline red cell production in hematologically stable patients with uremia. J Lab Clin Med. 1995;126:283-6.

22. Hocken AG. Haemolysis in chronic renal failure. Nephron. 1982;32:28-31.

23. Schwartz AB, Kahn SB, Kelch B, Kim KE, Pequignot E. RBC improved survival due to recombinant human erythropoietin explains effectiveness of less frequent, low dose subcutaneous therapy. Clin Nephrol. 1992;38:283-9.

24. Singh AK, Milford E, Fishbane S, Keithi-Reddy SR. Managing anemia in dialysis patients: hemoglobin cycling and overshoot. Kidney Int. 2008;74: 679-83.

\section{Submit your next manuscript to BioMed Central and we will help you at every step:}

- We accept pre-submission inquiries

- Our selector tool helps you to find the most relevant journal

- We provide round the clock customer support

- Convenient online submission

- Thorough peer review

- Inclusion in PubMed and all major indexing services

- Maximum visibility for your research

Submit your manuscript at www.biomedcentral.com/submit

Biomed Central 